屋上緑化植物「常緑キリンソウ」（Phedimus sp.）の品種保護および品種開発に向け た DNA マーカーの開発

糀 妙子 1) ・藤田道明 ${ }^{1)} \cdot \mathrm{Seong}-\mathrm{Woo} \mathrm{Cho}^{2)}$ ・辻本 壽 ${ }^{2)}$

1) (株) フジタ，鳥取県岩美郡， $=681-0052$

2) 鳥取大学乾燥地研究センター, 鳥取県鳥取市, テ 680-0001

\title{
Development of DNA markers in 'Evergreen Kirinso' (Phedimus sp.), a roof greening plant, for cultivar identification and breeding
}

Taeko Koji ${ }^{1)}$, Michiaki Fujita ${ }^{1)}$, Seong-Woo $\mathrm{Cho}^{2)}$ and Hisashi Tsujimoto ${ }^{2)}$

1) Fujita Co., Ltd., Iwami 681-0052, Japan

2) Arid Land Research Center, Tottori University, Tottori 680-0001, Japan

キーワード

常緑キリンソウ (Phedimus sp.), 品種識別, DNA マーカー, RAPD, SSR, PCR

\section{緒 言}

キリンソウ (Phedimus aizoon 異名: Sedum aizoon) は, ベンケイソウ科に属する多肉性多年草であり, 分布 域は日本から東アジアである。山地や海岸の岩場などに 自生し, 形態的な多様性が大きい. 野生種は冬季に地上 部が枯れ落ち，冬芽を形成して休眠する。近縁種にエゾ ノキリンソウ (Phedimus kamtschaticus), タケシマキリン ソウ (Sedum takesimense) 等がある.

(株) フジタ（鳥取県岩美郡岩美町）は冬季に地上部に より多くの緑を保つょら品種改良を行い,「トットリフジ タ 1 号」(品種登録第 15866 号) 拈よび「トットリフジタ 2 号」(品種登録第 15867 号)（図 1) を開発した。これら は品種登録され，「常緑キリンソウ」の通称で呼ばれてい る. 常緑キリンソウは, 屋上緑化, 法面緑化, 壁面緑化 など，様々な場所での緑化用植物として広く利用されて いる，常緑キリンソウは乾燥，湿潤扣よび高温，低温と いった様々な環境ストレスに強い、厳しい環境に扣いて も自然降雨のみでの生育が可能であるため, 灌水設備の 設置を必要としない。そのため，低コスト，低メンテナ ンスの緑化が行える優れた植物である.

今後も市場拡大が見込まれる常緑キリンソウである が，挿し木によって容易に栄養繁殖が可能であるため,

編集委員 : 安井 秀

2017 年 3 月 29 日受領 2017 年 11 月 27 日受理

2018 年 3 月 21 日 J-STAGE 早期公開

Correspondence: tsujim@alrc.tottori-u.ac.jp
品種保護のための品種識別マーカー開発が必要であった. また，現在市場に出ている品種は「トットリフジタ 1 号」 のみであり, 新しい品種の開発が望まれていた。しかし ながら, 常緑キリンソウの遺伝学的研究はなく, これら の開発は困難であった.

そこで本研究では, sequence-tagged site (STS) マーカー および simple sequence repeats（SSR）マーカーの作製を 行った. また, 常緑キリンソウの花粉および種子の調査 を行った.さらに，体細胞㧍よび花粉母細胞に扣ける染 色体を調査した.

\section{材料および方法}

\section{1. 植物材料}

常緑キリンソウ品種「トットリフジタ 1 号」,「トット リフジタ 2 号」, 富山, 柏崎, 佐渡の自生集団より採集し た, 3 系統のキリンソウ (P. aizoon), さらに, 園芸店（ア ルペンガーデンやまくさおよび大木ナーサリー）から購 入したタケシマキリンソウ（S. takesimense）を用いた.

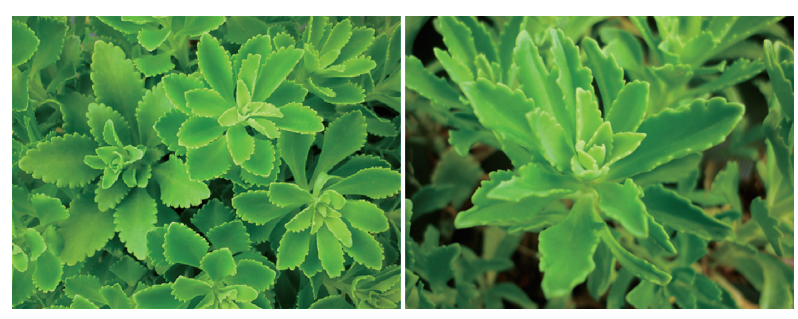

図 1.「トットリフジタ 1 号」（左）打よび「トットリフジタ 2 号」（右）の草姿. 
これらのタケシマキリンソウは，それぞれ $\mathrm{A}$ および $\mathrm{B}$ と して区別した.

\section{2. 花粉および種子の観察}

6 月に屋外で開花した「トットリフジタ 1 号」の花か ら成熟花粉を採集し，これを酢酸カーミンで染色後，光 学顕微鏡で調查した。また同じ植物を放任受粉させ， 2 か月後に種子の結実率を調査した。得られた種子はホル モンを添加しない MS 培地に播種し, 発芽率を調査した。 MS 培地の作製には，ムラシゲ・スクーグ培地用混合塩 類（日本製薬株式会社）を用いた。 ビタミン類の調整は, 大澤・久保田（2009）に基づいて行った.

\section{3. 染色体観察}

体細胞分裂観察用の試料は, 「トットリフジタ 1 号」の 根端を約 $1 \mathrm{~cm}$ 切り取り, 隇菌水に入れ， $0^{\circ} \mathrm{C} ， 24$ 時間の 前処理を行い, 室温のファーマー液で 5 日間固定して作 製した。この試料を酢酸カーミンで 20 分間染色し，押し つぶし法によりプレパラートを作り，位相差顕微鏡 （OLYMPUS BX 41）で観察した。減数分裂観察用試料 は, 屋外で生育した「トットリフジタ 1 号」の花蕾（2$7 \mathrm{~mm}$ ）をファーマー液に入れ，室温で 7 日間固定し作製 した。 実体顕微鏡の下で葯から未熟な花粉を取り出し, 酢酸カーミンで 2 分間染色して位相差顕微鏡で観察した.

\section{4. 品種識別のための STS および SSR マーカーの作製}

上記 7 種類の植物の展開直後の若い葉 $0.1 \mathrm{~g}$ (新鮮重)

を, 液体窒素中で涷結粉砕した後, MagExtractor -Plant Genome-（TOYOBO）を用い，そのプロトコルにしたがっ てDNAを抽出した.

STS マーカーの作製のため，まず，常緑キリンソウ 2 品種とキリンソウ 3 系統の DNA を鋳型にし， 20 種類の RAPD プライマー（Operon 社，Kit A) でPCR を行った. PCR に用いた反応液の構成は, ゲノム DNA $50 \mathrm{ng}$, RAPD プライマー7.5 pmol, 10×EX Taq Buffer (Takara Bio, Shiga, Japan) $2.5 \mu \mathrm{l}$, dNTP mix (2.5 mM, Takara Bio) $5 \mathrm{nmol}$, HybriPol DNA ポリメラーゼ（Bioline, London, UK） $0.6 \mathrm{U}$ を合わせて全量 $25 \mu \mathrm{l}$ とした。 PCR は， $94^{\circ} \mathrm{C} て ゙ 3$ 分間処 理後, 変性を $94^{\circ} \mathrm{C}$ で 1 分間, アニーリングを $34^{\circ} \mathrm{C} て ゙ 1$ 分 間，伸長を $72^{\circ} \mathrm{C} て ゙ 2$ 分間を 1 サイクルとし，これを 45 サイクル反復した後, 最後に $73^{\circ} \mathrm{C} て ゙ 5$ 分間の条件で行っ た. PCR 増幅産物を電気泳動で分離し, 植物間で増幅さ れる DNA 断片のサイズの多型性から, 品種識別に利用 できそうな特異的バンドを探索した。そののち，800 bp 以下のものについて，STS 化を試みた。 これら， STS 化 プライマーを用いて，常緑キリンソウ品種 2 品種とキリ ンソウ 3 系統, 抢よびタケシマキリンソウ 2 系統の DNA を鋳型とし，PCR を行ったＰPCR に用いた反応液の構成

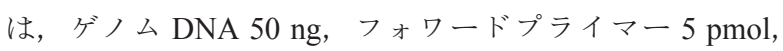
リバースプライマー 5 pmol, KAPA Taq Extra Hot Start
Ready Mix PCR Kit（KAPA BIOSYSTEMS） $12.5 \mu$ をを合わ せて全量 $25 \mu \mathrm{l}$ とした。 $\mathrm{PCR}$ は, $94^{\circ} \mathrm{C} て ゙ 5$ 分間処理後, 変性を $94^{\circ} \mathrm{C} て ゙ ~ 30$ 秒間，アニーリングを 30 秒間（アニー リング温度はプライマーによって異なる), 伸長を $72^{\circ} \mathrm{C}$ で 15 秒間を 1 サイクルとし，これを 35 サイクル反復し た後, 最後に $72^{\circ} \mathrm{C} て ゙ 7$ 分間の条件で行った. PCR 終了 後, $2 \%$ アガロースゲルで電気泳動を行い, 多型の確認を 行った.

SSR マーカーの作製は，練・宝月（2004）の方法にし たがって行った。その方法を簡単仁記載すると付図 1 の ようになる。「トットリフジタ 1 号」の DNAを制限酢素 HaeIII で切断し, その両端に, 48 mer の長鎖 DNA（5'GTAATACGACTCACTATAGGGCACGCGTGGTCGACGG CCCGGGCTGGT-3'）と 3'末端をアミノ化した $8 \mathrm{mer} の$ 短 鎖 DNA（5'-ACCAGCCC-NH - $_{2}-3^{\prime} ）$ から成る不等長アダプ ターをライゲーションした。次に，アダプタ一配列と同 じ配列を含むアダプター特異的プライマーAP1（5'CCATCGTAATACGACTCACTATAGGGC-3') , AP2 (5'CTATAGGGCACGCGTGGT-3') を用意した. プライマー $\mathrm{AP} 2$ と, SSR 配列( $\mathrm{AC})_{10}$ または(AG) $)_{10}$ を用いて $\mathrm{PCR}$ を行 い, SSR 配列に隣接する配列のうち片側を増幅した。増 幅産物をクローニングし, 挿入部分の塩基配列を決定し た、その配列それぞれに対して，フォワードプライマー となるプライマーIP1，IP2を新たに設計した。次に， 「トットリフジタ 1 号」の DNA を制限酵素 EcoRV, AluI, RsaI, HincII, SspI で切断し，アダプター付き断片を作製 した。 6 種類のアダプター付き断片々れぞれを鋳型に, nested PCR を行った. まず，プライマーIP1 と AP1 を用 いて PCR を行った後, その PCR 産物を鋳型にプライマー IP2 と AP2 を用いて PCR を行った。十分な長さのシング ルバンドが出たものをダイレクトシーケンスし，配列を 決定した。この，SSR 配列に隣接する配列のらちもら片 側の配列を元にリバースプライマーとなるプライマーIP3 を設計した。作製したプライマーIP1 とIP3 のペアを用 いて，ゲノム PCR を行った. 鋳型とするゲノム DNA は, 上に述べた植物 7 種類を用いた。 PCR に用いた反応液 は，ゲノム DNA $50 \mathrm{ng}$ ，プライマー IP1（フォワードプラ イマー) $10 \mathrm{pmol}$ ，プライマーIP3（リバースプライマー） 10 pmol, KAPA Taq Extra Hot Start Ready Mix PCR Kit （KAPA BIOSYSTEMS） $12.5 \mu \mathrm{l}$ を合わせて全量 $25 \mu \mathrm{l}$ とし た. $\mathrm{PCR}$ は, $94^{\circ} \mathrm{C}$ で 9 分間処理後, 変性を $94^{\circ} \mathrm{C} て ゙ 30$ 秒

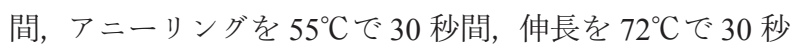
間を 1 サイクルとし, これを 40 サイクル反復した後, 最 後に $72^{\circ} \mathrm{C} て ゙ 5$ 分間の条件で行った. PCR 終了後, $3 \%$ ア ガロースゲルで電気泳動を行い, 多型の確認を行った.

\section{結 果}

\section{1. 花粉および種子の観察}

裂開直後の葯から採取した花粉粒を 345 粒調べたとこ 
ろ，そのらち 284 粒が内容物を含む正常な形態の花粉で あった（花粉稔性 82.3\%)．残りの 61 粒（17.7\%）は不稔 花粉であり，そのうち内容物を含まず染色されないもの 60 粒 (17.4\%)，粒の大ささおよび染色が不十分なもの 1 粒 $(0.3 \%)$ であった（図 $2 i ）$. 正常な花粉は直径 $17 \mu \mathrm{m}$ から $25 \mu \mathrm{m}$ で, 原形質全体が均一に染色されて 3 個の発 芽口が確認できた．不稔花粉は $10 \mu \mathrm{m}$ から $18 \mu \mathrm{m}$ の大き さであり内容物を欠いていた.

また，放任受粉させた「トットリフジタ 1 号」の 73 の 子房に含まれていた 713 粒の種子の形態を調査した結 果，厚みのある種子と厚みのない種子の 2 型が存在する ことが分かった。厚みのある種子は 713 粒の内 4 粒 $(0.6 \%)$ ，厚みのない種子は 709 粒 $(99.4 \%)$ であった. これらの種子を MS 培地に播種したところ，厚みのある 種子は発芽したため正常な種子であることが分かった. また，厚みのない種子は発芽せず粃であることが分かっ た.よって，「トットリフジタ 1 号」の結実率（総胚珠数 に占める結実種子数の割合）は $0.6 \%$ と非常に低いことが 明らかになった。多数の子房から厚みのある種子のみを 196 粒集め, これらをホルモンフリー MS 培地に播種し たところ，157粒が正常に発芽した。 よって，「トットリ フジタ 1 号」より得られた種子に打ける発芽率は $80.1 \%$ であった．播種後 8 か月後の時点で合計 112 個体の次代 が得られた。これら次代個体は全て常緑性であったが, 葉の形態，大きさ，色や草姿の伸長程度などの形質が個 体ごとに異なっていた（付図 2). 葉の形態については, 細葉や内側に湾曲した葉, 鋸歯の深い葉が観察された. また，葉色は濃い緑色から黄緑色を呈するものや，葉の 末端部が白く変色したものが観察された. しかしながら，
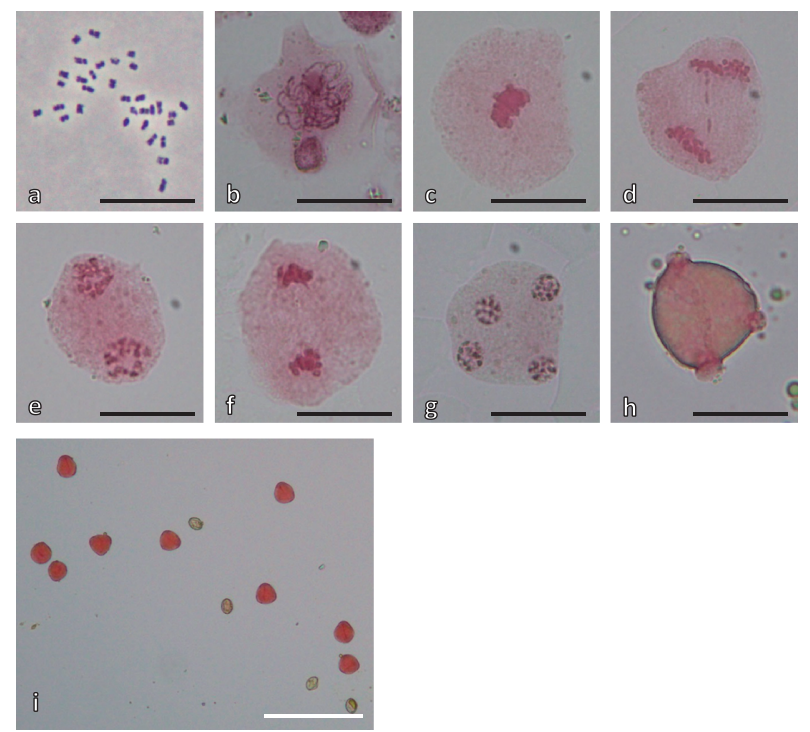

図 2.「トットリフジタ 1 号」の体細胞の染色体 (a), 減数分裂 の様子（b-g) 抢よび「トットリフジタ 1 号」の花粉（h, i). $\mathrm{b}$ : 第一分裂前期, $\mathrm{c}$ : 第一分裂中期, $\mathrm{d}$ : 第一分裂後 期, e : 第一分裂終期, $\mathrm{f}$ : 第二分裂中期, $\mathrm{g}$ : 四分子期, $\mathrm{h}, \mathrm{i}:$ 花粉. 黒いバーは $20 \mu \mathrm{m}$, 白いバーは $100 \mu \mathrm{m}$ を示す.
明瞭に分離する形質は見られなかった。

\section{2. 染色体観察}

体細胞分裂の観察のため根端の 5 細胞で染色体数を調 査した結果,「トットリフジタ 1 号」の染色体数は $2 \mathrm{n}=$ 32 であることが分かった，中期に拉いて染色体の全長は $1.4 \mu \mathrm{m}$ から $2.6 \mu \mathrm{m}$ であり, 染色体間で長さに大きな差は なかった．動原体は明瞭に現れ，24 本の中部動原体染色 体と 8 本の次中部動原体染色体が存在した（図 $2 \mathrm{a}$ ).

減数分裂の観察では, $2 \mathrm{~mm}$ の花蕾に含まれている葯か ら, 減数分裂の各分裂ステージの細胞が観察された（図 2b-g). 一方， $3 \mathrm{~mm}$ 以上の花蕾に含まれている葯では， 減数分裂が完了しており花粉を形成していた（図 $2 \mathrm{~h}$ ). 減数分裂第一中期に拈いては，全ての染色体が二価染色 体を形成しており，多価あるいは一価染色体は見られな かった. しかし，後期および終期に拈いて若干の染色体 橋が見られ，このことは逆位へテロの存在を示唆するも のであった。しかし, 減数分裂は扮括むね正常であり, 正常な四分子を形成した。

\section{3. 品種識別のための STS および SSR マーカーの作製 \\ 1） STS マーカーの作製}

20 の RAPD プライマーを用いて PCR を行った結果, OPA-07, OPA-10, OPA-16, OPA-20 の 4 プライマーによ り多型バンドが得られた（付図 3)。 OPA-07, OPA-10, OPA-20により得られた多型バンドは「トットリフジタ 1 号」と「トットリフジタ 2 号」に共通であり，OPA-16に より得られた多型バンドは「トットリフジタ 1 号」のみ に特異的であった. これらの多型バンドをもとに STS 化 を行らために，それぞれのバンドの塩基配列を解読し， その配列を元に 20 または 23 mer のプライマーを設計し た.これらのプライマーを用いて 7 種類の植物について PCR を行い, 多型性の再確認を行った. その結果, RAPD プライマー OPA-07, OPA-10, OPA-16 によるバンドから 得られた塩基配列を元に設計した 3 組の STS プライマー （付表 1）に抢いて，多型を示すバンドが得られた（図 3). これらの STS マーカーA-07, A-10, A-16のバンドサイ ズはそれぞれ 449, 661，拈よび 401 bp であった。

これら 3 個の STS マーカーに拈けるバンドは, いずれ も「トットリフジタ 1 号」と「トットリフジタ 2 号」の 2 品種間で同一であった. STS マーカーA-07 に拈いて は，「トットリフジタ 1 号」拈よび「トットリフジタ 2 号」の 2 品種のみに特異的なバンドが見られた。 また, タケシマキリンソウ A とタケシマキリンソウ $\mathrm{B}$ の 2 系統 は, 全てのSTS マーカーにおいて同一のバンドパターン を示した。

\section{2） SSR マーカーの作製}

SSR 配列を含む配列 25 種類を決定し，それぞれの配列 から SSR 配列を含む断片を増幅するプライマーとなる フォワードプライマーIP1 拈よびリバースプライマー IP3 


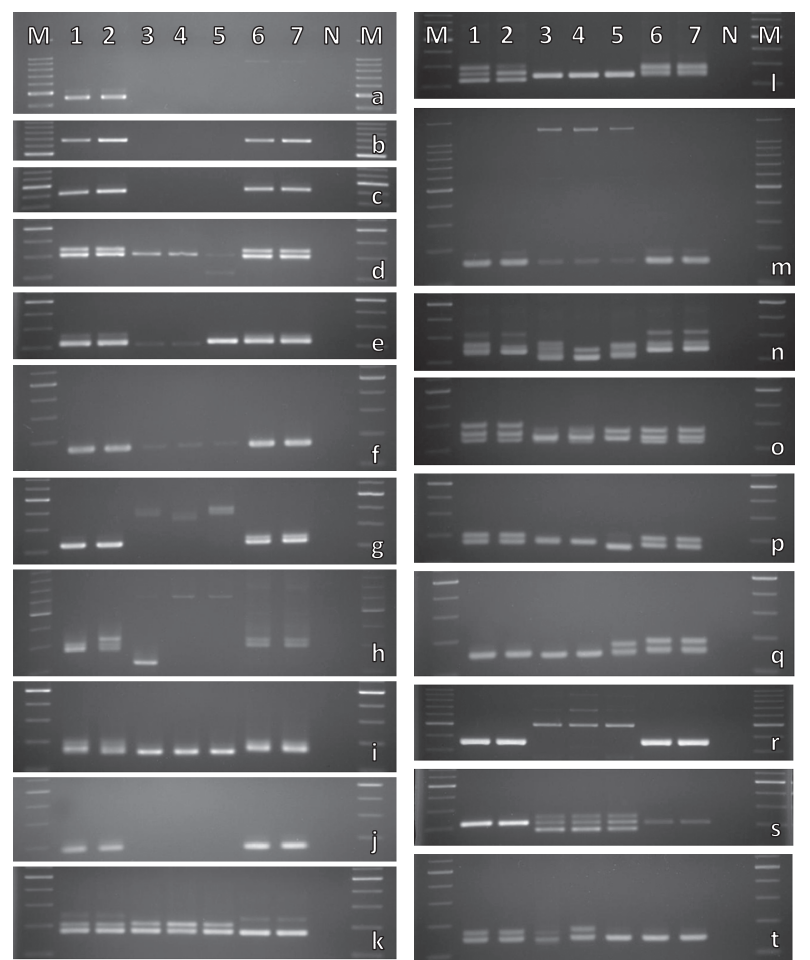

図 3. STS マーカーおよびSSR マーカーの電気泳動像. M : 分 子量マーカー (100 bp DNA Ladder), 1 :「トットリフジタ 1 号」, 2 :「トットリフジタ 2 号」, 3: キリンソウ野生系 統 (富山), 4: キリンソウ野生系統 (柏崎), 5: キリンソ ウ野生系統 (佐渡), 6: タケシマキリンソウ $\mathrm{A}, 7$ : タケ シマキリンソウ $\mathrm{B}, \mathrm{N}$ ：ネガティブコントロール，a： A-07-2, b : A-10-2, c : A-16-2, d:251-IP1 と IP3, e : 299IP1 と IP3, f : 263-IP1 と IP3, g : 274-IP1 と IP3, h : 293IP1 と IP3, i : 332-IP1 と IP3, j : 353-IP1 と IP3, $\mathrm{k}:$ : 257IP1 と IP3, $1: 260-\mathrm{IP} 1$ と IP3, $\mathrm{m}: 298$-IP1 と IP3, $\mathrm{n}: 366-$ IP1 と IP3, o : 370-IP1 と IP3, p : 376-IP1 と IP3, q : 384IP1 と IP3, $\mathrm{r}:$ :235-IP1 と IP3, s : 238-IP1 と IP3, $\mathrm{t}:$ 322IP1 と IP3 により増幅.

を 25 組設計した. フォワードプライマー IP1 とリバース プライマーIP3 を用いて植物 7 種類について PCR を行 い, 多型性の調査を行った. その結果, 17 のSR マー カー（付表 2）を用いた際に，いずれかの系統において 多型を示すバンドが得られた（図 3).

17 の SSR マーカーのらち 1 マーカー（図 3h）は「トッ トリフジタ 1 号」と「トットリフジタ 2 号」の間でバン ドパターンの違いが明瞭で，識別可能であった。 2 マー カー (図 $31, \mathrm{n})$ は, 「トットリフジタ 1 号」と「トットリ フジタ 2 号」の間でバンドパターンの違いが不明瞭で識 別困難であった。

6 マーカー（図 $3 \mathrm{~g}, \mathrm{k}, 1, \mathrm{o}, \mathrm{q}, \mathrm{t}$ ) は, 「トットリフジタ 1 号」拈よび「トットリフジタ 2 号」を, タケシマキリン ソウ 2 個体と明確に識別可能であったが，2 マーカー（図 3h,s）については識別困難であった.

いずれの SSR マーカーも, タケシマキリンソウ A とタ ケシマキリンソウ $\mathrm{B}$ に多型を示さなかった.

\section{考察}

\section{1. 花粉および種子の観察と染色体観察}

従来「トットリフジタ 1 号」の種子は確認されて扣ら ず，不稔品種であろらと考えられて来た。しかし，本研 究によって, 正常な減数分裂を行い花粉稔性も高いこと が明らかとなった。しかし，種子結実率は $0.6 \%$ と低いも のであった。次世代からは多様な形態を示す個体が得ら れ，今後，自殖や他の系統との交配による育種の可能性 があることを示すことができた。

な扣，今回の研究で「トットリフジタ 1 号」の体細胞 染色体数は 32 本であることが分かった. タケシマキリン ソウの染色体数は $2 \mathrm{n}=32$ (Weiss et al. 2002), キリンソウ の染色体数は $2 \mathrm{n}=32$ から 102 まで生息域によって様々で ある (Amano 1990).「トットリフジタ 1 号」の染色体数 は,タケシマキリンソウ拈よび一部のキリンソウと同数 であるが, Amano（1990）によるとキリンソウの染色体 の基本数は $\mathrm{x}=8$ であることから, 四倍性であると考学ら れる.「トットリフジタ 1 号」の減数分裂に拉いては，四 価染色体は見られなかったが，コルヒチンにより倍加し た四倍性のソバのように，同質倍数性でも注とんど二価 染色体を示す植物もあるので，これらが同質倍数体か異 質倍数体かは分からない.

\section{2. 品種識別のための STS および SSR マーカーの作製}

本研究で「トットリフジタ 1 号」と「トットリフジタ 2 号」の品種識別に利用可能な特異的バンドパターンを 示す STS マーカーを 3 個, SSR マーカーを 17 個作製す ることができた。「トットリフジタ 1 号」拉よび「トット リフジタ 2 号」については過去に塩基配列の情報がなく, DNA マーカーもなかった。本研究で作製したこれらの DNA マーカーは品種識別に有用であり，品種の保護に利 用できる、マーカー開発を行った当時品種登録されてい た品種は，「トットリフジタ 1 号」执よび「トットリフジ タ 2 号」の 2 品種のみであった. キリンソウおよびタケ シマキリンソウの野生個体は, 本研究で比較対象として 用いた以外にも様々な遺伝子型の個体が存在していると 考学らる。本研究で開発したDNA マーカーを用いて 品種識別を行ら際，その目的は，調査する植物が「トッ トリフジタ 1 号」なのか,「トットリフジタ 2 号」なの か，それ以外の個体なのかを決定することとしている。 本論文に記載した方法により，高い再現性で明確に品種 識別が可能である。

SSR マーカーは一般的に共優性であり，対立遺伝子の 数が多いため品種識別に適している。これまでにもイネ やチャなど数多くの植物種に拈いて高い多型性が示され ている（河野ら 2000, 加藤ら 2008）. 本研究においても 開発した SSR マーカーは複数本のバンドを示すものが多 くあり (図 $3 n$, o など), キリンソウの品種識別に拈いて も SSR マーカーの有用性が示された. 
特異的なバンドを示した全 20 マーカーの内 1 個の SSR マーカーに拈いて，「トットリフジタ 1 号」と「トットリ フジタ 2 号」の間で明瞭なバンドパターンの違いが見ら れた（図 3h）。この 2 品種は互いに近縁であるといわれ ているが，このマーカーは，「トットリフジタ 1 号」に近 縁な個体間での識別にも有用である. タケシマキリンソ ウ $\mathrm{A}$ とタケシマキリンソウ $\mathrm{B}$ の 2 系統は, いずれのマー カーでも識別できず，これらはクローンである可能性が 高い.

\section{電子付録}

付表 1. 多型を示した STS マーカーのプライマー配列 付表 2. 多型を示した SSR マーカーのプライマー配列 付図 1. SSR マーカーの作製方法 付図 2.「トットリフジタ 1 号」から得られた次代の草姿 付図 3. RAPD プラィマーでの電気泳動像

\section{謝 辞}

本研究の一部は農水省による品種保護に向けた DNA 品種識別技術実用化事業の支援を受けて実施された。

\section{引用文献}

Amano, M. (1990) Bot. Mag., Tokyo. 103: 67-85.

大澤勝次・久保田旺（2009）農学基礎セミナー＼cjkstart植物バイテク の実際, 農山漁村文化協会, 東京. 228.

加藤史子 ・ 谷口郁也・物部真奈美・江間か扣り ・廣野久子・山 本（前田）万里（2008）日本食品科学工学会誌 55: 49-55. 河野いら゙久・竹内善信・島野公利・佐々木卓治・矢野昌裕 (2000) 育種学研究 2: 49-55.

練 春蘭・宝月岱造（2004）日本林學會誌 86: 191-198.

Weiss, H., B.-Y. Sun, T.F. Stuessy, C.H. Kim, H. Kato and M. Wakabayashi (2002) Bot. J. Linn. Soc. 138: 93-105. 